\title{
RENTABILITAS PERUSAHAAN AGRIBISNIS DI BURSA EFEK INDONESIA (BEI)
}

\author{
Eggidia Octafiani S \\ Leonardus R. Rengkung \\ Lyndon R. J. Pangemanan
}

\begin{abstract}
This study aims to analyze the rentability of Agribusiness Companies on the Indonesia Stock Exchange (IDX). This research was conducted for 2 months from May to June 2018. The data used in this study is secondary data obtained from 3 companies, namely PT. Astra Agro Lestari Tbk (AALI), PP London Sumatra Tbk (LSIP) and PT Sawit Sumbermas Sarana Tbk (SSMS), the data collection has been reported to the Indonesia Stock Exchange (BEI) Manado City Branch. The results of the study show that PT. SSMS Tbk has a rentability that consists of ROA, ROE, GPM, NPM, which is higher than PT. AALI Tbk, and PT. LSIP Tbk. This means that PT SSMS gets the highest profit. ${ }^{*}$ lrr+eprm*.
\end{abstract}

Keywords: Rentability, Agribusiness Companies, Indonesia Stock Exchange (IDX)

\begin{abstract}
ABSTRAK
Penelitian ini bertujuan untuk menganalisis Rentabilitas Perusahaan Agribisnis di Bursa Efek Indonesia (BEI). Penelitian ini dilakukan selama 2 bulan dari bulan Mei sampai dengan Juni 2018. Data yang digunakan dalam penelitian ini adalah data sekunder yang diperoleh dari 3 perusahaan yaitu PT. Astra Agro Lestari Tbk (AALI), PP London Sumatera Tbk (LSIP) dan PT Sawit Sumbermas Sarana Tbk (SSMS), Pengumpulan data tersebut telah dilaporkan kepada Bursa Efek Indonesia (BEI) Cabang kota Manado. Hasil penelitian menunjukkan bahwa PT. SSMS Tbk memiliki Rentabilitas yang terdiri atas ROA, ROE, GPM, NPM, yang lebih tinggi dibandingkan PT. AALI Tbk, dan PT. LSIP Tbk. Artinya PT SSMS mendapat laba tertinggi. *rrreprm*.
\end{abstract}

Kata kunci: Rentabilitas, Perusahaan Agribisnis, Bursa Efek Indonesia

\section{PENDAHULUAN}

\section{Latar Belakang}

Agroindustri merupakan industri yang menggunakan bahan baku pertanian. Pengembangan industri ini dapat memberikan nilai tambah serta menyediakan keragaman produk makanan. Produk pertanian yang biasanya diolah adalah tanaman hortikultura dan palawija. Kacang tanah merupakan tanaman palawija yang dapat diolah untuk bahan baku industri.

Bursa Efek Indonesia merupakan bursa hasil penggabungan dari Bursa Efek Jakarta (BEJ) dengan Bursa Efek Surabaya (BES). Untuk memberikan informasi yang lebih lengkap tentang perkembangan bursa kepada publik, BEI menyebarkan data pergerakan harga saham melalui media cetak dan elektronik. Perusahaan yang sudah go public memutuskan untuk menjual sahamnya kepada publik dan siap untuk dinilai oleh publik secara terbuka, melalui Bursa Efek Indonesia.

BEI mempunyai beberapa jenis indeks, diantaranya Indeks Harga Saham Gabungan (IHSG), Indeks Individual, Indeks LQ45, Indeks IDX 30, Indeks Kompas 100, Jakarta Islamic Indeks (OJK), Indeks Investor33, dan Indeks Sektoral. Indeks Sektoral merupakan indeks saham yang masuk dalam sektor yang sama terdiri dari 9 sektor yang mencantumi komponen komponennya yaitu Pertanian, Pertambangan, Industri Dasar, Aneka Industri, Industri Barang Konsumsi, Properti, Infrastruktur, Keuangan dan Perdagangan (BEI, 2018). 
LQ 45 adalah indeks pasar saham di Bursa Efek Indonesia (BEI) yang terdiri dari 45 perusahaan yang memenuhi kriteria tertentu, yaitu termasuk dalam top 60 perusahaan dengan kapitalisasi pasar tertinggi dalam 1-2 bulan terakhir, termasuk dalam top 60 perusahaan dengan nilai transaksi tertinggi di pasar reguler dalam 12 bulan terakhir, telah tercatat di Bursa Efek Indonesia selama minimal 3 bulan, memiliki kondisi keuangan, prospek pertumbuhan dan nilai transaksi yang tinggi, indeks LQ 45 dihitung setiap enam bulan oleh divisi penelitian dan pengembangan Bursa Efek Indonesia.

Indeks Sektoral dalam BEI termasuk Sektor pertanian, terdiri dari, Tanaman Pangan, Perkebunan, Peternakan dan Perikanan, untuk sektor perkebunan memiliki 12 perusahaan yang tercatat di BEI yaitu; Astra Agro Lestari Tbk, BW Plantation Tbk, Gozco Plantations Tbk, Jaya Agra Wattie Tbk, Multi Agro Gemilang Plantation Tbk, Provident Agro Tbk, PP London Sumatra Tbk, Salim Ivomas Pratama Tbk, Sampoerna Agro Tbk. Rengkung (2012) mengatakan bahwa sebagai perusahaan public, maka semua perusahaan yang listed akan selalu berupaya untuk meningkatkan kinerjanya, dalam rangka menjaga kestabilan harga sahamnya. Semaoen (1996) menjelaskan bahwa agribisnis adalah suatu kegiatan usaha yang berkaitan dengan sektor agribisnis mencakup perusahaan yang pemasok input agribisnis dan jasa pengangkutan,jasa keuangan.

Sudana (2011) menjelaskan Rentabilitas adalah kemampuan perusahaan untuk menghasilkan laba dengan menggunakan sumbersumber yang dimiliki perusahaan, seperti aktiva, modal atau penjualan perusahaan. Kasmir (2014) menjelaskan rentabilitas suatu perusahaan dapat diukur menggunakan rumus Return On Assets (ROA), Return On Equity (ROE), Gross Profit Margin (GPM), Net Profit Margin (NPM). Perusahaan Agribisnis dalam indeks sektoral pertanian yang termasuk dalam LQ 45 yaitu, Astra Agro Lestari Tbk, PP London Sumatera Tbk dan Sawit Sumbermas Sarana Tbk.

\section{Rumusan Masalah}

Berdasarlan uraian latar belakang di atas maka rumusan masalah penelitian ini adalah bagaimana Rentabilitas Perusahaan Agribisnis di Bursa Efek Indonesia (BEI) ?

\section{Tujuan Penelitian}

Tujuan penelitian ini adalah menganalisis Rasio Rentabilitas Perusahaan Agribisnis di Bursa Efek Indonesia (BEI).

\section{Manfaat Penelitian}

Manfaat yang diberikan penelitian ini adalah sebagai berikut.

1. Mengetahui Rentabilitas Perusahaan Agribisnis di Bursa Efek Indonesia

2. Bagi Akademisi dan peneliti, berdasarkan hasil yang disimpulkan dari penelitian ini diharapkan dapat mendukung teori atau hasil penelitian terdahulu mengenai topik yang sama di bidang Agribisnis ataupun pandangan dan wawasan baru, yang akan mendukung keberadaan dan perkembangan Agribisnis Pertanian. Bagi Lembaga/ Perusahaan, Dapat mengetahui perkembangan Perusahaan melalui Analisis Rentabilitas Perusahaan Agribisnis di Busra efek Indonesia.

\section{METODE PENELITIAN}

\section{Waktu dan Objek Penelitian}

Penelitian ini dilakukan pada PT Astra Agro Lestari Tbk (AALI), PP London Sumatera Tbk (LSIP) dan PT Sawit Sumbermas Sarana Tbk (SSMS) perusahaan Agribisnis yang terdaftar pada Bursa Efek Indonesia (BEI) berdasarkan data yang dipublikasi BEI tahun 2015 - 2017. Waktu yang digunakan selama penelitian ini kurang lebih 2 bulan dari bulan Mei sampai dengan Juni 2018.

\section{Sumber Data}

Data yang digunakan dalam penelitian ini adalah data sekunder yang diperoleh dari PT. Astra Agro Lestari Tbk (AALI), PP London Sumatera Tbk (LSIP) dan PT Sawit Sumbermas Sarana Tbk (SSMS), melalui Bursa Efek Indonesia (BEI), data tersebut berupa Laporan Keuangan tahun 2015- 2017.

\section{Analisis Data}

Analisa data dalam penelitian ini memakai Analisis Rasio Rentabilitas, dengan menghitung; 
1. Rentabilitas Ekonomi (ROA)

$$
\mathrm{ROA}=\frac{\text { Laba Sebelum Pajak }}{\text { Total Aset/Aktiva }} \times 100 \%
$$

2. Rentabilitas Modal Sendiri (ROE)

$$
\mathrm{ROE}=\frac{\text { Laba Bersih Setelah Pajak }}{\text { Ekuitas }} \times 100 \%
$$

\section{Gross Profit Margin (GPM)}

$$
\mathrm{GPM}=\frac{\text { Laba Kotor }}{\text { Pendapatan }} \times 100 \%
$$

\section{Net Profit Margin (NPM)}

$$
\mathrm{NPM}=\frac{\text { Laba Bersih Setelah Pajak }}{\text { Pendapatan }} \times 100 \%
$$

*Keterangan

Aset : Semua hak yang dapat digunakan dalam perusahaan

Ekuitas : Hak residual atas aktiva perusahaan setelah dikurangi semua kewajiban dalam neraca

Laba kotor : Pendapatan dikurangi biaya pokok penjualan

Pendapatan : Jumlah nilai uang yang masuk ke perusahaan dari barang atau jasa yang dijualnya

Laba Sebelum Pajak : Nilai akhir setelah laba usaha dikurangi peng-hasil (beban) lain-lain tadi

Laba Sesudah Pajak : Laba sebelum pajak dikurangi beban pajak

\section{HASIL DAN PEMBAHASAN}

\section{Gambaran Umum Objek Penelitian}

Data penelitian yang digunakan dalam penelitian ini adalah perusahaan Agribisnis yang terdaftar di Bursa Efek Indonesia (BEI) dalam LQ 45 .

\section{PT. Astra Agro Lestari Tbk}

Astra Agro Lestari Tbk (AALI) didirikan dengan nama PT Suryaraya Cakrawala tanggal 3 Oktober 1988, yang kemudian berubah menjadi PT Astra Agro Niaga tanggal 4 Agustus 1989. Perusahaan mulai beroperasi komersial pada tahun 1995. Kantor pusat AALI dan anak usaha (Grup) berlokasi di Jalan Pulo Ayang Raya Blok OR - I, Kawasan Industri Pulogadung, Jakarta 13930 - Indonesia. Perkebunan kelapa sawit AALI saat ini berlokasi di Kalimantan Selatan dan pabrik minyak goreng berlokasi di Sumatra Utara. Perkebunan dan pabrik pengolahan entitas anak berlokasi di pulau Jawa, Sumatra, Kalimantan, dan Sulawesi.

\section{PP London Sumatera Indonesia Tbk}

Perusahaan Perkebunan London Sumatra Indonesia Tbk (LSIP) didirikan tanggal 18 Desember 1962 dan mulai beroperasi secara komersial pada tahun 1962. Kantor pusat LSIP terletak di Ariobimo Sentral Lt. 12, Jln. HR. Rasuna Said Blok X-2 Kav. 5, Jakarta 12950 Indonesia, sedangkan kantor cabang operasional berlokasi di Medan, Palembang, Makassar, Surabaya dan Samarinda. Induk usaha dari Lonsum adalah Salim Ivomas Pratama Tbk / SIMP, dimana SIMP memiliki 59,48\% saham yang ditempatkan dan disetor penuh Lonsum, sedangkan induk usaha terakhir dari Lonsum adalah First Pacific Company Limited, Hong Kong.

\section{PT Sawit Sumbermas Sarana Tbk}

Sawit Sumbermas Sarana Tbk (SSMS) didirikan tanggal 22 November 1995 dan mulai beroperasi secara komersial pada tahun 2005. Kantor pusat SSMS beralamat di Jl. Haji Udan Said No. 47, Pangkalan Bun - 74113, Kalimantan Tengah, dan memiliki kantor perwakilan di Equity Tower, 43 F Suite 43 D Jl. Jend. Sudirman Kav.5253 SCBD Lot 9 Jakarta 12190 - Indonesia. Sedangkan perkebunan kelapa sawit dan pabrik kelapa sawit berlokasi di Arut Selatan, Kotawaringin Barat, Kalimantan Tengah. Pemegang saham yang memiliki 5\% atau lebih saham Sawit Sumbermas Sarana Tbk adalah PT Citra Borneo Indah $(26,46 \%)$, PT Prima Sawit Borneo (13,65\%), PT Putra Borneo Agro Lestari (13,65\%), PT Mandiri Indah Lestari (13,65\%), Falcon Private Bank Ltd $(8,43 \%)$ dan Jemmy Adriyanor (6,55\%).

\section{Rasio Rentabilitas PT. AALI Tbk, PP. LSIP Tbk, PT. SSMS Tbk}

Rasio Rentabilitas digunakan untuk mengukur kemampuan perusahaan memperoleh laba bersih dan memperoleh keuntungan, dengan memperhatikan total asset, total ekuitas, pendapatan, laba kotor juga laba bersih, dalam laporan keuangan peusahaan. 
Semakin tinggi nilai rasio rentabilitas pada ROE, ROA, GPM dan NPM, berpengaruh pada semakin baiknya kinerja serta posisi keuangan perusahaan. Rasio Rentabilitas memudahkan para penanam saham untuk menganalisa kondisi perusahaan.

Perusahaan - perusahaan Agribisnis yang tercatat di BEI dalam LQ 45 merupakan perusahaan blue chip yang memiliki pendapatan stabil dan nilai saham yang tinggi, dengan menghitung rasio rentabilitas memperlihatkan bagaimana perusahaan mampu mengolah asset sehingga menghasilkan keuntungan.

\section{PT. Astra Agro Lestari Tbk}

Tabel 1 dan Gambar 1 menunjukkan bahwa hasil perhitungan rentabilitas ekonomi PT. AALI Tbk, tahun 2015 adalah setiap total asset 100 mampu memperoleh laba sebelum beban pajak sebesar 5,47. pada tahun 2016 adalah total asset 100 mampu memperoleh laba sebelum beban pajak sebesar 9,11 dan pada tahun 2017 setiap total asset 100 mampu memperoleh laba sebelum beban pajak sebesar 11,78. Mengalami kenaikan disetiap tahunnya disebabkan total asset yang naik mampu menaikan laba.

\begin{tabular}{cccrr}
\multicolumn{5}{l}{ Tabel 1. Rentabilitas Ekonomi PT. AALI Tbk, Tahun 2015 s.d 2017} \\
\hline No. Tahun & $\begin{array}{c}\text { Laba Bersih Sebelum } \\
\text { Pajak }^{*} \text { (dalam jutaan rupiah) }\end{array}$ & $\begin{array}{c}\text { Total Asset } \\
\text { (dalam jutaan rupiah) }\end{array}$ & ROA (\%) \\
\hline 1 & 2015 & 1.175 .513 & 21.512 .371 & 5,47 \\
2 & 2016 & 2.208 .778 & 24.226 .122 & 9,11 \\
3 & 2017 & 2.938 .505 & 24.935 .426 & 11,76 \\
\hline
\end{tabular}

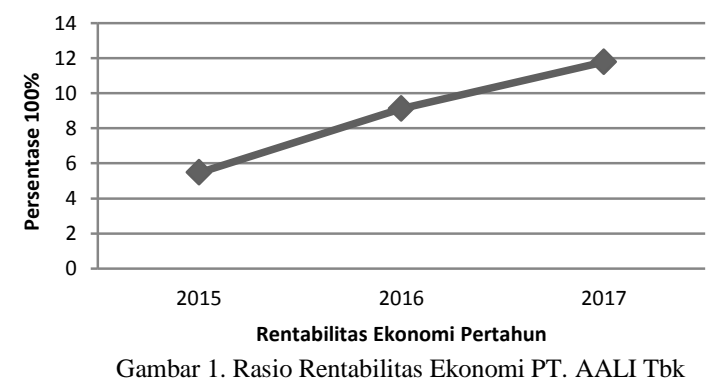

Tahun 2015 s.d 2017

Tabel 2 dan Gambar 2 menunjukkan bahwa hasil perhitungan di atas, rentabilitas modal sendiri PT. AALI Tbk, mengalami persentase naik turun, pada tahun 2016 dengan total ekuitas yang meningkat perusahaan mampu manghasilkan laba lebih besar dibandingkan tahun sebelumnya dan pada tahun 2017 total ekuitas meningkat namun perusahaan menghasilkan laba yang kecil sehingga rasio rentabilitasnya menurun.
Tabel 2. Rentabilitas Modal Sendiri PT. AALI Tbk, Tahun 2015 s.d 2017

\begin{tabular}{rrrrr}
\hline No. Tahun & $\begin{array}{c}\text { Laba Bersih Setelah Pajak* } \\
\text { (dalam jutaan rupiah) }\end{array}$ & $\begin{array}{c}\text { Total Ekuitas* } \\
\text { (dalam jutaan rupiah) }\end{array}$ & ROE (\%) \\
\hline 1 & 2015 & 695.684 & 11.698 .787 & 5,95 \\
2 & 2016 & 2.114 .299 & 17.593 .482 & 12,02 \\
3 & 2017 & 2.113 .629 & 18.536 .438 & 11,40 \\
\hline
\end{tabular}

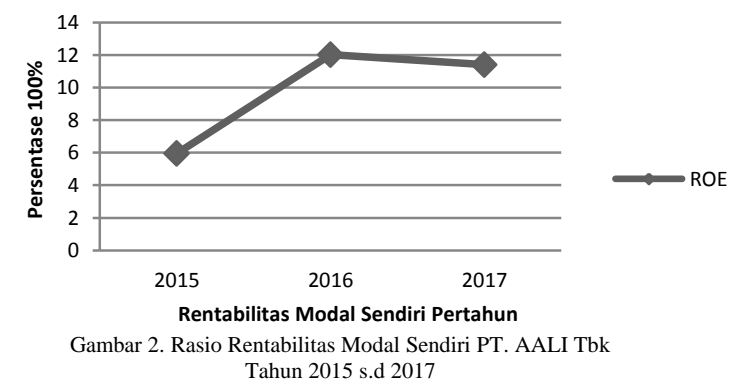

Tabel 3 dan Gambar 3 menunjukkan bahwa hasil perhitungan di atas Gross Profit Margin PT. AALI Tbk, pada tahun 2015 adalah setiap pendapatan 100 mampu memperoleh laba kotor sebesar 23,60 pada tahun 2016 adalah setiap pendapatan 100 mampu memperoleh laba kotor sebesar 26,03 pada tahun 2017 setiap pendapatan 100 mampu memperoleh laba kotor sebesar 23,95. mengalami presentasi naik turun dikarenakan laba kotor ang dihasilkan perusahaan mengurangi pendapatan.

\begin{tabular}{ccccr}
\multicolumn{5}{l}{ Tabel 3. Gross Profit Margin PT. AALI Tbk, Tahun 2015 s.d 2017 } \\
\hline No. Tahun & $\begin{array}{c}\text { Laba Kotor** } \\
\text { (dalam jutaan rupiah) }\end{array}$ & $\begin{array}{c}\text { Pendapatan** } \\
\text { (dalam jutaan rupiah) }\end{array}$ & GPM (\%) \\
\hline 1 & 2015 & 3.082 .098 & 13.059 .216 & 23,60 \\
2 & 2016 & 3.676 .014 & 14.121 .374 & 26,03 \\
3 & 2017 & 4.145 .250 & 17.305 .688 & 23,95 \\
\hline
\end{tabular}

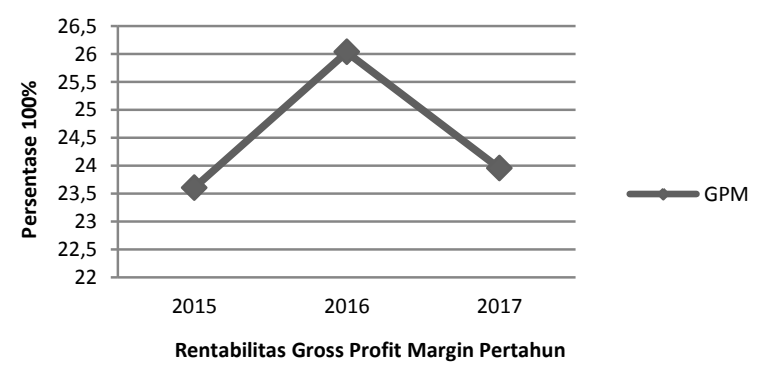

Gambar 3. Rasio Rentabilitas Gross Profit Margin PT. AALI Tahun 2015 s.d 2017

Tabel 4 dan Gambar 4 menunjukkan bahwa Net Profit Margin PT. AALI Tbk, pada tahun 2015 setiap pendapatan 100 mampu memperoleh laba bersih setelah pajak sebesar 5,33 pada tahun 2016 setiap pendapatan 100 mampu memperoleh laba bersih setelah pajak sebesar 14,97 pada tahun 2017 setiap pendapatan 100 mampu memperoleh laba kotor sebesar 12,21 mengalami presentase naik turun. Hal tersebut disebabkan pengaruh pendapatan laba bersih setelah pajak dalam perusahaan tidak stabil dengan pendapatan, sehingga perusahaan mengalami persentasi naik turun. 
Tabel 4. Net Profit Margin PT. AALI Tbk, Tahun 2015 s.d 2017

\begin{tabular}{cccrr}
\hline No. & Tahun & $\begin{array}{c}\text { Laba Bersih Setelah Pajak* } \\
\text { (dalam jutaan rupiah) }\end{array}$ & $\begin{array}{c}\text { Pendapatan** } \\
\text { (dalam jutaan rupiah) }\end{array}$ & NPM (\%) \\
\hline 1 & 2015 & 3.082 .098 & 13.059 .216 & 23,60 \\
2 & 2016 & 3.676 .014 & 14.121 .374 & 26,03 \\
3 & 2017 & 4145.250 & 17.305 .688 & 23,95 \\
\hline
\end{tabular}

\begin{tabular}{lllll}
2 & 2016 & 3.676 .014 & 14.121 .374 & 26,03 \\
3 & 2017 & 4.145 .250 & 17.305 .688 & 23,95 \\
\hline
\end{tabular}

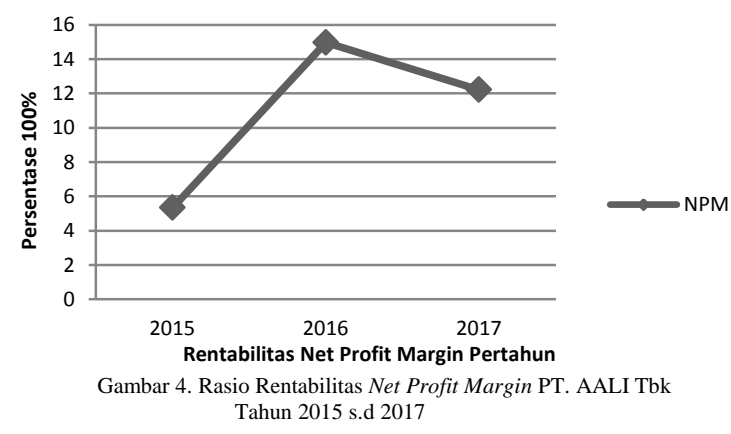

PP London Sumatra Indonesia Tbk

Tabel 5 dan Gambar 5 menunjukkan bahwa hasil perhitungan di atas rentabilitas ekonomi PP. LSIP Tbk, pada tahun 2015 adalah setiap total asset 100 mampu memperoleh laba sebesar 9,35 pada tahun 2016 total asset 100 mampu memperoleh laba sebesar 8,23 dan pada tahun 2017 setiap total asset 100 mampu memperoleh laba sebesar 8,46. Nilai yang dihasilkan perusahaan di tahun 2016 dan 2017 menurun jika dibandingkan dengan tahun 2015, karena Total Asset perusahaan tidak bisa menghasilkan laba bersih sebelum pajak di tahun tersebut sehingga mengalami penurunan ROA.

Tabel 5. Rentabilitas Ekonomi PP. LSIP Tbk, Tahun 2015 s.d 2017

\begin{tabular}{ccccc}
\hline No. & Tahun & $\begin{array}{c}\text { Laba Bersih Sebelum Pajak* } \\
\text { (dalam jutaan rupiah) }\end{array}$ & $\begin{array}{c}\text { Total Asset** } \\
\text { (dalam jutaan rupiah) }\end{array}$ & ROA (\%) \\
\hline 1 & 2015 & 827.882 & 8.848 .792 & 9,35 \\
2 & 2016 & 778.561 & 9.459 .088 & 8,23 \\
3 & 2017 & 827.838 & 9.786 .628 & 8,46 \\
\hline
\end{tabular}

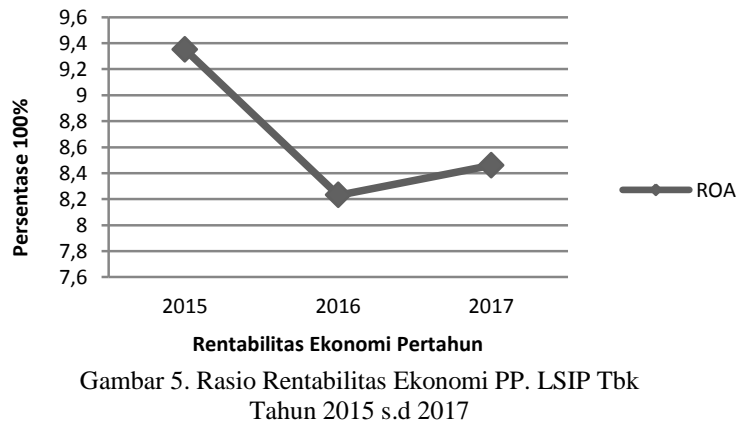

Tabel 6 dan Gambar 6 menunjukkan bahwa rentabilitas modal sendiri PP LSIP Tbk, pada tahun 2015 adalah setiap modal sendiri 100 mampu memperoleh laba sebesar 8,49 pada tahun 2016 setiap modal sendiri 100 mampu memperoleh laba sebesar 7,75 pada tahun 2017 setiap modal sendiri 100 mampu memperoleh laba sebesar 7,96 mengalami persentase turun naik, hal tersebut disebabkan pada tahun 2016 laba bersih dan ekuitas sama-sama mengalami peningkatan, pada tahun 2017 laba bersih menurun namun ekuitas meningkat.

\begin{tabular}{ccccc}
\multicolumn{5}{c}{ Tabel 6. Rentabilitas Modal Sendiri PP. LSIP Tbk, Tahun 2015 s.d 2017 } \\
\hline No. & Tahun & $\begin{array}{c}\text { Laba Bersih Setelah Pajak* } \\
\text { (dalam jutaan rupiah) }\end{array}$ & $\begin{array}{c}\text { Total Ekuitas** } \\
\text { (dalam jutaan rupiah) }\end{array}$ & ROE (\%) \\
\hline 1 & 2015 & 623.309 & 7.337 .978 & 8,49 \\
2 & 2016 & 592.769 & 7.645 .984 & 7,75 \\
3 & 2017 & 639.686 & 8.045 .539 & 7,96 \\
\hline
\end{tabular}

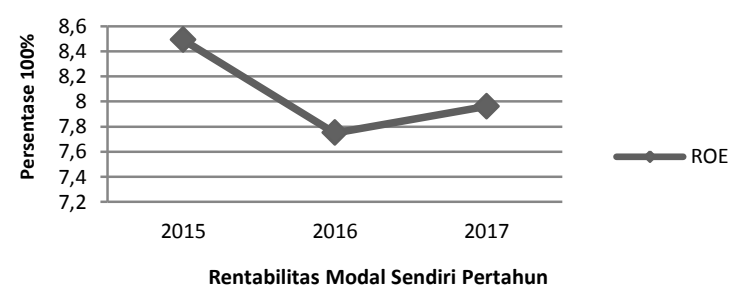

Gambar 6. Rasio Rentabilitas Modal Sendiri PP. LSIP Tbk Tahun 2015 s.d 2017

Tabel 7 dan Gambar 7 menunjukkan bahwa Gross Profit Margin PT.PP LSIP Tbk, pada tahun 2015 adalah setiap pendapatan 100 mampu memperoleh laba kotor sebesar 26,63 pada tahun 2016 setiap pendapatan 100 mampu memperoleh laba kotor sebesar 28,87 pada tahun 2017 setiap pendapatan 100 mampu memperoleh laba kotor sebesar 29,24. GPM mengalami kenaikan karna laba kotor perusahaan menurun dan pendapatan meningkat setiap tahunnya.

\begin{tabular}{|c|c|c|c|c|}
\hline No. & Tahun & $\begin{array}{c}\text { Laba Kotor* } \\
\text { (dalam jutaan rupiah) }\end{array}$ & $\begin{array}{c}\text { Pendapatan**( } \\
\text { (dalam jutaan rupiah) }\end{array}$ & GPM (\%) \\
\hline 1 & 2015 & 1.115 .841 & 4.189 .615 & 26,63 \\
\hline 2 & 2016 & 1.110 .785 & 3.847 .869 & 28,87 \\
\hline 3 & 2017 & 1.045 .166 & 3.574 .898 & 29,24 \\
\hline
\end{tabular}

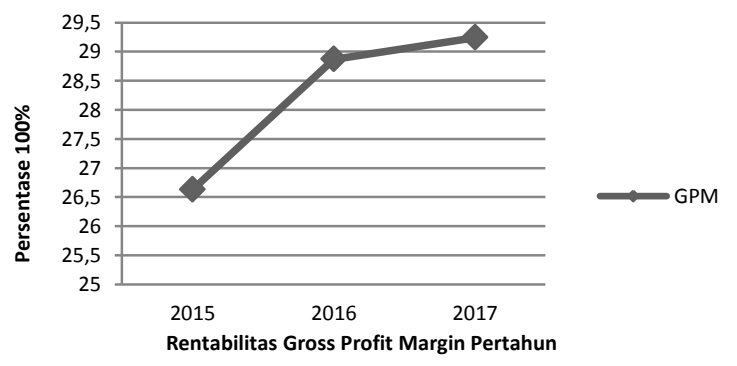

Gambar 7. Rasio Rentabilitas Gross Profit Margin PP. LSIP Tbk Tahun 2015 s.d 2017

Tabel 8 dan Gambar 8 menunjukkan bahwa Net Profit Margin PP LSIP Tbk, pada tahun 2015 adalah setiap pendapatan 100 mampu memperoleh laba bersih setelah pajak sebesar 14,88 pada tahun 2016 setiap pendapatan 100 mampu memperoleh laba bersih setelah pajak sebesar 15,41 pada tahun 
2017 setiap pendapatan 100 mampu memperoleh laba bersih setelah pajak sebesar 17,89, mengalami kenaikan setiap tahunnya, karena perusahaan mampu menghasilkan laba bersih dan pendapatan dengan baik setiap tahunnya.

Tabel 8. Net Profit Margin PP. LSIP Tbk, Tahun 2015 s.d 2017

\begin{tabular}{ccccc}
\hline No. & Tahun & $\begin{array}{c}\text { Laba Bersih Setelah Pajak* } \\
\text { (dalam jutaan rupiah) }\end{array}$ & $\begin{array}{c}\text { Pendapatan** } \\
\text { (dalam jutaan rupiah) }\end{array}$ & NPM (\%) \\
\hline 1 & 2015 & 623.309 & 4.189 .615 & 14,88 \\
2 & 2016 & 592.769 & 3.847 .869 & 15,41 \\
3 & 2017 & 639.686 & 3.574 .898 & 17,89 \\
\hline
\end{tabular}

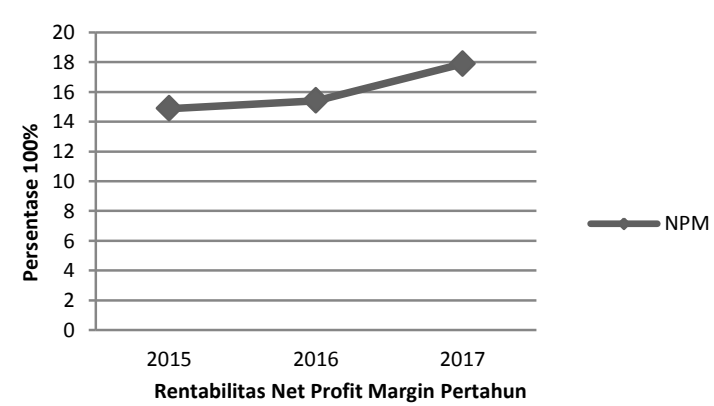

Gambar 8. Rasio Rentabilitas Net Profit Margin PP. LSIP Tbk Tahun 2015 s.d 2017

Tabel 9 dan Gambar 9 menunjukkan bahwa rentabilitas ekonomi PT.SSMS Tbk, pada tahun 2015 adalah setiap total asset 100 mampu memperoleh laba sebesar 11,12 pada tahun 2016 total asset 100 mampu memperoleh laba sebesar 11,83 mengalami kenaikan disbanding tahun 2015 karena nilai laba bersih sebelum pajak naik dan nilai total asset mengalami kenaikan dan pada tahun 2017 setiap total asset 100 mampu memperoleh laba sebesar 3,93 menurun karena nilai laba bersih sebelum pajak menurun sedangkan nilai total asset meningkat, sehingga berpengaruh pada penurunan laba perusahaan.

\begin{tabular}{lrrrr}
\multicolumn{6}{l}{ Tabel 9. Rentabilitas Ekonomi PT. SSMS Tbk, Tahun 2015 s.d 2017 } \\
\hline No. & Tahun & $\begin{array}{c}\text { Laba Bersih Sebelum Pajak* } \\
\text { (dalam jutaan rupiah) }\end{array}$ & $\begin{array}{c}\text { Total Asset** } \\
\text { (dalam jutaan rupiah) }\end{array}$ & ROA (\%) \\
\hline 1 & 2015 & 775.449 & 6.973 .851 & $11,12 \%$ \\
2 & 2016 & 847.388 & 7.162 .970 & $11,83 \%$ \\
3 & 2017 & 324.911 & 8.261 .550 & $3,93 \%$ \\
\hline
\end{tabular}

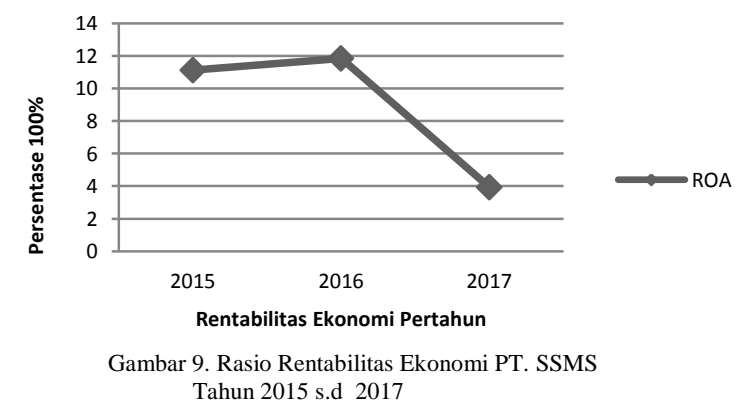

Tabel 10 dan Gambar 10 menunjukkan bahwa rentabilitas modal sendiri PT. SSMS Tbk, pada tahun 2015 adalah setiap modal sendiri 100 mampu memperoleh laba sebesar 19,35 pada tahun 2016 setiap modal sendiri 100 mampu memperoleh laba sebesar 17,13 pada tahun 2017 setiap modal sendiri 100 mampu memperoleh laba sebesar 6,50 mengalami persentase penurunan. hal tersebut disebabkan pada tahun 2016 laba bersih meningkat dibandingkan tahun 2015 dan ekuitas meningkat sedangkan tahun 2017 laba besih setelah pajak menurun dan ekuitas meningkat sehingga mengalami penurunan dibanding tahun 2015 dan 2016.

\begin{tabular}{lrrrr}
\multicolumn{5}{l}{ Tabel 10. Rentabilitas Modal Sendiri PT. SSMS Tbk, Tahun 2015 s.d 2017 } \\
\hline No. & Tahun & $\begin{array}{c}\text { Laba Bersih Setelah Pajak* } \\
\text { (dalam jutaan rupiah) }\end{array}$ & $\begin{array}{c}\text { Total Ekuitas** } \\
\text { (dalam jutaan rupiah) }\end{array}$ & ROE (\%) \\
\hline 1 & 2015 & 587.144 & 3.034 .052 & 19,35 \\
2 & 2016 & 591.659 & 3.453 .797 & 17,13 \\
3 & 2017 & 240.536 & 3.698 .421 & 6,50 \\
\hline
\end{tabular}

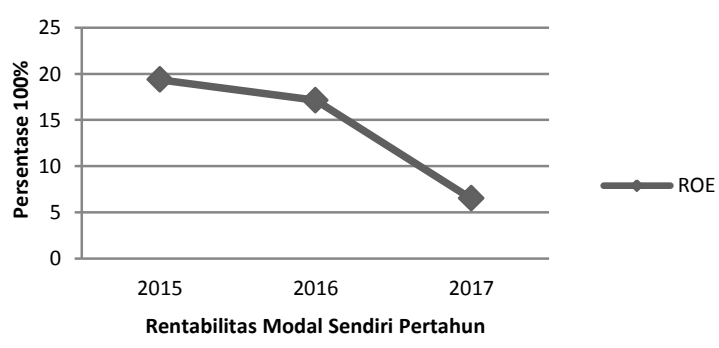

Gambar 10. Rasio Rentabilitas Modal Sendiri PT. SSMS Tbk Tahun 2015 s.d 2017

Tabel 11 dan Gambar 11 menunjukkan bahwa Gross Profit Margin PT.SSMS Tbk, pada tahun 2015 adalah setiap pendapatan 100 mampu memperoleh laba kotor sebesar 52,61 pada tahun 2016 setiap pendapatan 100 mampu memperoleh laba kotor sebesar 53,85 pada tahun 2017 setiap pendapatan 100 mampu memperoleh laba kotor sebesar 59,36 mengalami kenaikan yang baik setiap tahunnya hal tersebut di sebabkan karena kenaikan laba kotor lebih kecil dibandingkan kenaikan pendapatan di tiap tahunnya sehingga perusahaan mampu menghasilkan laba bersih dengan nilai yang tinggi.

\begin{tabular}{|c|c|c|c|c|}
\hline No. & Tahun & $\begin{array}{c}\text { Laba Kotor* } \\
\text { (dalam jutaan rupiah) }\end{array}$ & $\begin{array}{c}\text { Pendapatan** } \\
\text { (dalam jutaan rupiah) }\end{array}$ & $\overline{\mathrm{GPM}(\%)}$ \\
\hline 1 & 2015 & 1.247 .912 & 2.371 .878 & 52,61 \\
\hline 2 & 2016 & 1.466 .059 & 2.722 .678 & 53,85 \\
\hline 3 & 2017 & 424.654 & 715.360 & 59,36 \\
\hline
\end{tabular}




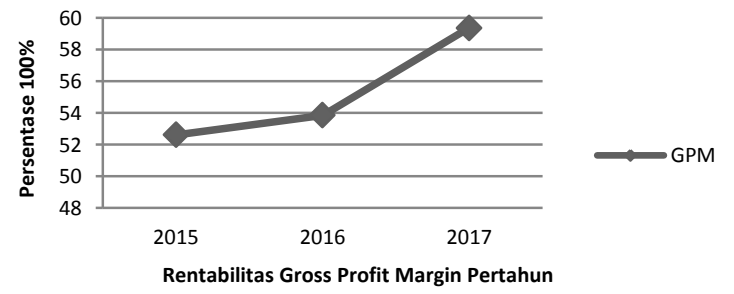

Gambar 11. Rasio Rentabilitas Gross Profit Margin PT. SSMS Tbk Tahun 2015 s.d 2017

Tabel 12 dan Gambar 12 menunjukkan bahwa Net Profit Margin PT. SSMS Tbk, pada tahun 2015 adalah setiap pendapatan 100 mampu memperoleh laba bersih setelah pajak sebesar 24,75 pada tahun 2016 setiap pendapatan 100 mampu memperoleh laba bersih setelah pajak sebesar 21,73 pada tahun 2017 setiap pendapatan 100 mampu memperoleh laba bersih setelah pajak sebesar 33,62 mengalami presentase naik turun. Hal tersebut disebabkan pada tahun 2016 selisih kenaikan laba bersih setelah pajak lebih kecil dibandingkan selisih kenaikan pendapatan, kemudian pada tahun 2017 mengalami kenaikan karena perusahaan menghasilkan laba tinggi pada tingkat penjualan tertentu dan dapat menekan biaya.

\begin{tabular}{lcccc}
\multicolumn{6}{c}{ Tabel 12. } & Net Profit Margin PT. SSMS Tbk, Tahun 2015 s.d 2017 \\
\hline No. & Tahun & $\begin{array}{c}\text { Laba Bersih Setelah Pajak* } \\
\text { (dalam jutaan rupiah) }\end{array}$ & $\begin{array}{c}\text { Pendapatan** } \\
\text { (dalam jutaan rupiah) }\end{array}$ & NPM (\%) \\
\hline 1 & 2015 & 587.144 & 2.371 .878 & $24,75 \%$ \\
2 & 2016 & 591.659 & 2.722 .678 & $21,73 \%$ \\
3 & 2017 & 240.536 & 715.360 & $33,62 \%$ \\
\hline
\end{tabular}

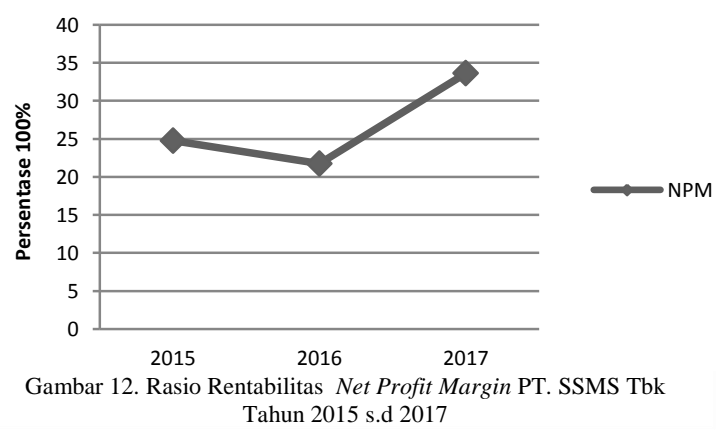

Tabel 13 dan Gambar 13 menunjukkan bahwa Rasio Rentabilitas Ekonomi dapat dilihat PT. SSMS Tbk, memiliki persentase rasio lebih tinggi pada tahun 2015 s.d 2016 dibandingkan PT. AALI Tbk dan PP. LSIP Tbk, namun menurun di tahun 2017. PT. AALI Tbk menunjukkan kenaikan rasio dari tahun 2015 s.d 2017. Rasio Rentabilitas PP. LSIP Tbk berada diantara keduanya sedikit menurun di tahun 2016 namun mengalami kenaikan di tahun 2017.
Tabel 13. Rasio Rentabilitas Ekonomi PT. AALI Tbk, PP. LSIP Tbk, PT. SSMS Tbk, Tahun 2015 s.d 2017

\begin{tabular}{lccc}
\hline & \multicolumn{3}{c}{ ROA } \\
\cline { 2 - 4 } & 2015 & 2016 & 2017 \\
\hline AALI & 5.47 & 12.02 & 11.78 \\
LSIP & 9.35 & 7.75 & 8.46 \\
SSMS & 11.12 & 17.13 & 3.93 \\
\hline
\end{tabular}

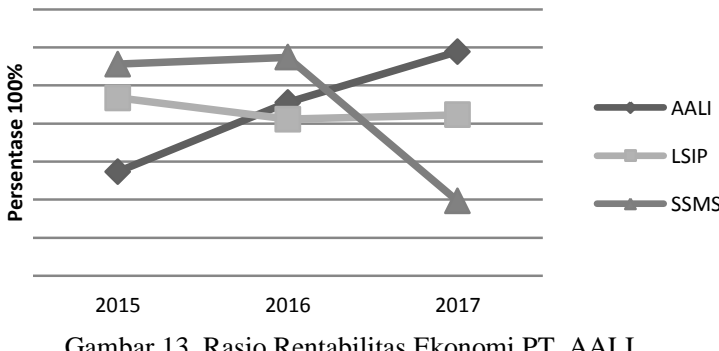

Tabel 14 dan menunjukkan bahwa Rasio Rentabilitas Modal Sendiri, PT. SSMS Tbk menghasilkan persentase yang lebih tinggi pada tahun 2016 s.d 2016. PT. AALI Tbk mengalami peningkatan ditahun 2016 namun belum melebihi PT. SSMS Tbk, PP LSIP Tbk menunjukkan sedikit penurunan dan kenaikan persentase di tahun 2016 s.d 2017.

Tabel 14. Rasio Rentabilitas Modal Sendiri PT. AALI Tbk, PP. LSIP Tbk, PT. SSMS Tbk, tahun 2015 s.d 2017

\begin{tabular}{lccc}
\hline & \multicolumn{3}{c}{ ROE } \\
\cline { 2 - 4 } & 2015 & 2016 & 2017 \\
\hline AALI & 5.95 & 12.02 & 11.40 \\
LSIP & 8.49 & 7.75 & 7.95 \\
SSMS & 19.35 & 17.13 & 6.50 \\
\hline
\end{tabular}

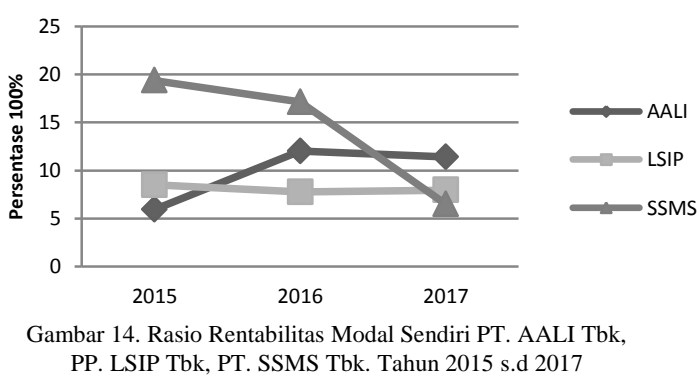

Tabel 15 dan Gambar 15 menunjukkan bahwa Gross Profit Margin, tahun 2015 s.d 2017 PT. SSMS Tbk menghasilkan persentase yang lebih tinggi dibandingkan PP. LSIP Tbk dan PT. AALI Tbk, PP. LSIP mengalami kenaikan persentase dibandingkan PT. AALI.

Tabel 15. Rasio Rentabilitas Gross Profit Margin PT. AALI Tbk, PP. LSIP Tbk, PT. SSMS Tbk, tahun 2015 s.d 2017

\begin{tabular}{llll}
\hline & \multicolumn{3}{c}{ GPM } \\
\cline { 2 - 4 } & 2015 & 2016 & 2017 \\
\hline AALI & 23.60 & 26.03 & 23.95 \\
LSIP & 26.63 & 28.87 & 29.24 \\
SSMS & 52.61 & 53.85 & 59.36 \\
\hline
\end{tabular}




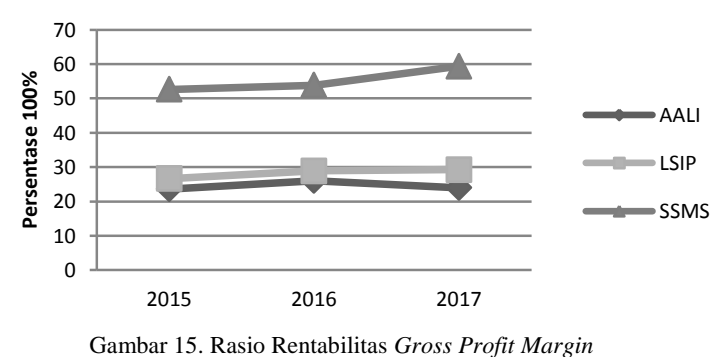

PT. AALI Tbk, PP. LSIP Tbk, PT. SSMS Tbk. Tahun 2015 s.d 2017

Tabel 16 dan Gambar 16 menunjukkan bahwa Net Profit Margin, tahun 2015 s.d 2017 PT. SSMS Tbk menghasilkan persentase yang lebih tinggi dibandingkan PP. LSIP Tbk dan PT. AALI Tbk. Tahun 2016 PT. AALI Tbk mengalami kenaikan persentase hampir mendekati persentase PP. LSIP Tbk dan pada tahun 2017 PP. LSIP Tbk mengalami kenaikan persentase di atas PT. AALI Tbk.

Tabel 16. Rasio Rentabilitas Net Profit Margin PT. AALI Tbk, PP. LSIP Tbk, PT. SSMS Tbk, tahun 2015 s.d 2017

\begin{tabular}{llll}
\hline & \multicolumn{3}{c}{ NPM } \\
\cline { 2 - 4 } & 2015 & 2016 & 2017 \\
\hline AALI & 5.33 & 14.97 & 12.21 \\
LSIP & 14.88 & 15.41 & 17.89 \\
SSMS & 24.75 & 21.73 & 33.62 \\
\hline
\end{tabular}

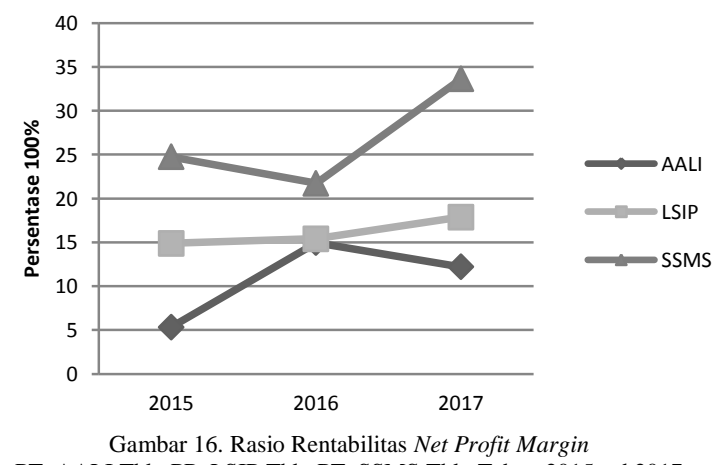

PT. AALI Tbk, PP. LSIP Tbk, PT. SSMS Tbk. Tahun 2015 s.d 2017

\section{KESIMPULAN DAN SARAN}

\section{Kesimpulan}

Rasio Rentabilitas Perusahaan dapat menunjukkan posisi perusahaan dalam aspek kemampuan perusahaan menghasilkan keuntungan. Perusahaan Agribisnis PT. SSMS Tbk memiliki Rasio Rentabilitas ROA, ROE, GPM, NPM, yang lebih tinggi dibandingkan PT. AALI Tbk, dan PP.LSIP Tbk, di tahun 2015 s.d 2017. PT. SSMS Tbk menunjukkan kemampuan perusahaan dengan bertahan dalam saham LQ45 di Bursa Efek Indonesia (BEI). Penurunan atau kenaikan satu rasio tidak mempengaruhi persentase rasio yang lain, penurunan atau kenaikan rasio di tentukan dari perhitungan masing- masing unsur pada tahun berjalan. Persentase rasio yang tinggi menunjukkan posisi perusahaan yang baik.

\section{Saran}

Perusahaan Agribisnis, PT. AALI Tbk, PP. LSIP Tbk, dan PT. SSMS Tbk, dapat meningkatkan Rasio ROA, ROE, GPM dan NPM sambil memperbaiki hal-hal yang kurang seperti pada PT. AALI Tbk, biaya operasi perusahaan yang semakin tinggi di tiap tahunnya, berpengaruh terhadap penurunan persentase rasio GPM. PP LSIP Tbk, tingkat penjualan yang menurun dalam periode 2015 s.d 2017 dan PT. SSMS Tbk, total asset yang masih sedikit dari PT. AALI Tbk, dan PP. LSIP Tbk, namun menghasilkan laba yang efektif dan mempertahankan posisinya dalam saham LQ 45.

\section{DAFTAR PUSTAKA}

IDX. Indeks Saham. Bursa Efek Indonesia. http://www.idx.co.id/data-pasar/laporanstatistik/ringkasan-performa-perusahaanlq45/. Diakses pada 28 Februari 2018.

Kasmir. 2014. Analisis Laporan Keuangan. Edisi Satu. Cetakan Ketujuh. PT Raja Grafindo Persada. Jakarta.

Rengkung, L. R. 2012. Dynamic Capabilities Perusahaan Agribisnis pada PT. Sampoerna Agro, Tbk dan PT.Bakrie Sumatera Plantations, Tbk. Disertasi.

Semaoen, I. 1996. Teori Mikro Ekonomi: Pendekatan Matematik. Program Pasca Sarjana Universitas Brawijaya. Malang.

Sudana, I. M. 2011. Manajemen Keuangan Perusahaan Teori dan Praktek. Erlangga. Jakarta.

Wikipedia. Bursa Efek Indonesia. Ensiklopedia Bebas.https://id.wikipedia.org/wiki/Bursa _efek. Diakses pada 28 Februari 2018. 